Article

\title{
Defining Benchmarks for Restoration of Green Infrastructure: A Case Study Combining the Historical Range of Variability of Habitat and Species' Requirements
}

\author{
Michael Manton ${ }^{1, *}$ (i) and Per Angelstam ${ }^{1,2}$ \\ 1 Faculty of Forest Science and Ecology, Institute of Forest Biology and Silviculture, \\ Aleksandras Stulginskis University, Studentu g. 13, LT-53362 Akademija, Kaunor, Lithuania; \\ per.angelstam@slu.se \\ 2 School for Forest Management, Swedish University of Agricultural Sciences, \\ SE-739 21 Skinnskatteberg, Sweden \\ * Correspondence: michael.manton@asu.lt; Tel.: +370-624-36824
}

Received: 19 December 2017; Accepted: 20 January 2018; Published: 30 January 2018

\begin{abstract}
Animal husbandry in Europe that sustained once wide-spread semi-natural grasslands has been replaced by maximum sustained yield agriculture and forestry. This transformation coincides with declining populations of species dependent on semi-natural grasslands. A key task is therefore to define benchmarks for landscape restoration in terms of well-planned functional habitat networks, i.e., green infrastructure. Using a representative example of the European landscape gradient between agricultural and forest landscapes in southern Sweden as a case study, we analyzed the historic range of variability of the total area, quality, and size of grassland patches, and compared this to the requirements of focal grassland species. Spatial data covering the past two centuries indicated a $75-80 \%$ loss of total grassland area. Three factors affected the functionality of grasslands as green infrastructure. First, during the period 1927-1976, the loss of all grassland areas with high nature values was $41-59 \%$. Second, as a measure of alteration, the number of semi-natural grassland types declined from 5 to 1 . Third, to address habitat fragmentation, an analysis of changes in grassland patch size showed that patches sufficiently large to support local populations of complete focal grasslands species assemblages declined by $89-100 \%$. The cumulative effect of loss, alteration, and fragmentation over the past two centuries indicates that the functionality of semi-natural grasslands has declined by at least $98 \%$. However, this estimate does not consider land use changes before 1800, reduced connectivity, and altered biotic and abiotic processes in both semi-natural grasslands and the surrounding matrix. We stress the need to define the historic range of variability as a benchmark in relation to species' requirements to maintain semi-natural grasslands as green infrastructure. Finally, integrated land management and governance that support multi-functionality of grasslands is needed.
\end{abstract}

Keywords: focal species; functional habitat networks; historical ecology; grasslands; land cover change; landscape patterns; range of variability; restoration ecology; traditional farming systems

\section{Introduction}

Intensive land management practices, such as maximum sustained yield agriculture and forestry, generally result in decreases of natural capital (e.g., [1]) at multiple spatial scales [2]. A wide range of studies have indicated that intensified management and use of natural and cultural land covers (e.g., forests, woodlands, and grasslands) has caused reductions in the composition, 
structure, and function of biodiversity [3-5]. Additionally, urbanization and development of transport infrastructure may directly and indirectly affect both land cover patterns and ecological processes $[6,7]$.

The solution is to establish ecological networks $[8,9]$ in terms of habitat patches with sufficient quality, size, and juxtaposition $[10,11]$. We define a functional habitat network as one that can maintain local populations of the most demanding focal species [12]. This requires spatial planning as a means for coordinated actions in the entire area hosting the focal habitat network. The EU's Green Infrastructure policy [13] maintains this ambition, and aims at conservation, management, and restoration of networks of strategically planned representative land cover patches, which are designed to conserve biodiversity, and to deliver a wide range of ecosystem services. However, implementation on the ground requires regionally specific assessment of the opportunity to maintain representative land cover types as functional networks.

Research on land-use history and land cover change forms an important avenue to generate knowledge about benchmarks for green infrastructure maintenance and facilitate learning towards understanding the development trajectories of functionality of habitat patch networks $[14,15]$ (by benchmark we mean evidence-based knowledge about how much (amount, quality, and patch size requirements) habitat is enough to maintain viable species population [16]). However, understanding the consequences of human activity on ecosystems also requires knowledge about the effects of habitat loss, land cover alteration, and fragmentation on species [17-19].

In Northern Europe, the integrated development of animal husbandry and agriculture had already created a cultural landscape by the medieval agricultural revolution (e.g., [20,21]). However, during the 20th century, a transition from those traditional practices for human livelihoods to a market-based food industry caused changes in land use and land covers [22]. Thus, once common semi-natural grasslands of traditional cultural landscapes suffered from reduced functionality as a habitat network, or green infrastructure, for biodiversity conservation [4]. As a result, approximately 22 out of 45 grassland habitat types have been declared as having an unfavorable to bad conservation status in northern Europe. Moreover, almost 50\% of bird species, which are relevant indicators of green infrastructure functionality, associated with grassland habitats have declined [23].

As a means of defining benchmarks for restoration of semi-natural grasslands, as one type of green infrastructure, the aim of this study is to analyze changes in the amounts, types, and sizes of grassland patches in relation to the needs of focal grassland species' over the last 200 years in a representative northern European forest-farmland gradient. Knowledge of the historic range of variability (see, [24]) and focal species requirements is critically important as an input for making decisions about the opportunities for maintaining functional habitat networks, and for subsequent spatial planning for functional habitat networks. We test the hypothesis that temporal changes have reduced the functionality of grassland patches as green infrastructure for biodiversity conservation with respect to three factors, viz. (1) loss of area, (2) alteration of quality (change in grassland type), and (3) fragmentation of large contiguous areas. Using a local landscape that hosts one of Sweden's most important wet grassland landscapes as a case study, we analyzed land cover change during the past two centuries. Stressing the need to apply evidence-based knowledge in landscape restoration, we discuss the pros and cons of current project-driven conservation management practices vs. place-based collaborative learning for the maintenance of different grassland types as green infrastructure by spatial planning.

\section{Materials and Methods}

We used the Kristianstad municipality $\left(1484 \mathrm{~km}^{2}\right)$ in southern Sweden (approx. $55 \mathrm{~N}, 14 \mathrm{E}$, Figure 1) as a representative example of the long term general transition from a multi-functional cultural landscape based on animal husbandry, and thus pastures and grasslands [25], to maximum sustained yield forestry and agriculture [26]. This municipality includes the downstream part of the River Helge å drainage basin, which transitions from forest uplands to agricultural lowland areas. Kristianstad remains one of Sweden's most important conservation areas for several types of 
grasslands. As a consequence of the degradation and recognition of the importance of the grasslands, several conservation initiatives have been established to try and manage the area sustainably [5]. The Kristianstad Vattenrike Biosphere Reserve, established in 2005, is one such example. To capture the unique and high natural and cultural landscape values, several priority land covers have been declared by the Kristianstad Vattenrike Biosphere Reserve. These include rich wet grasslands along the River Helge å, xeric and calcareous grasslands, and ancient wooded grasslands [27].
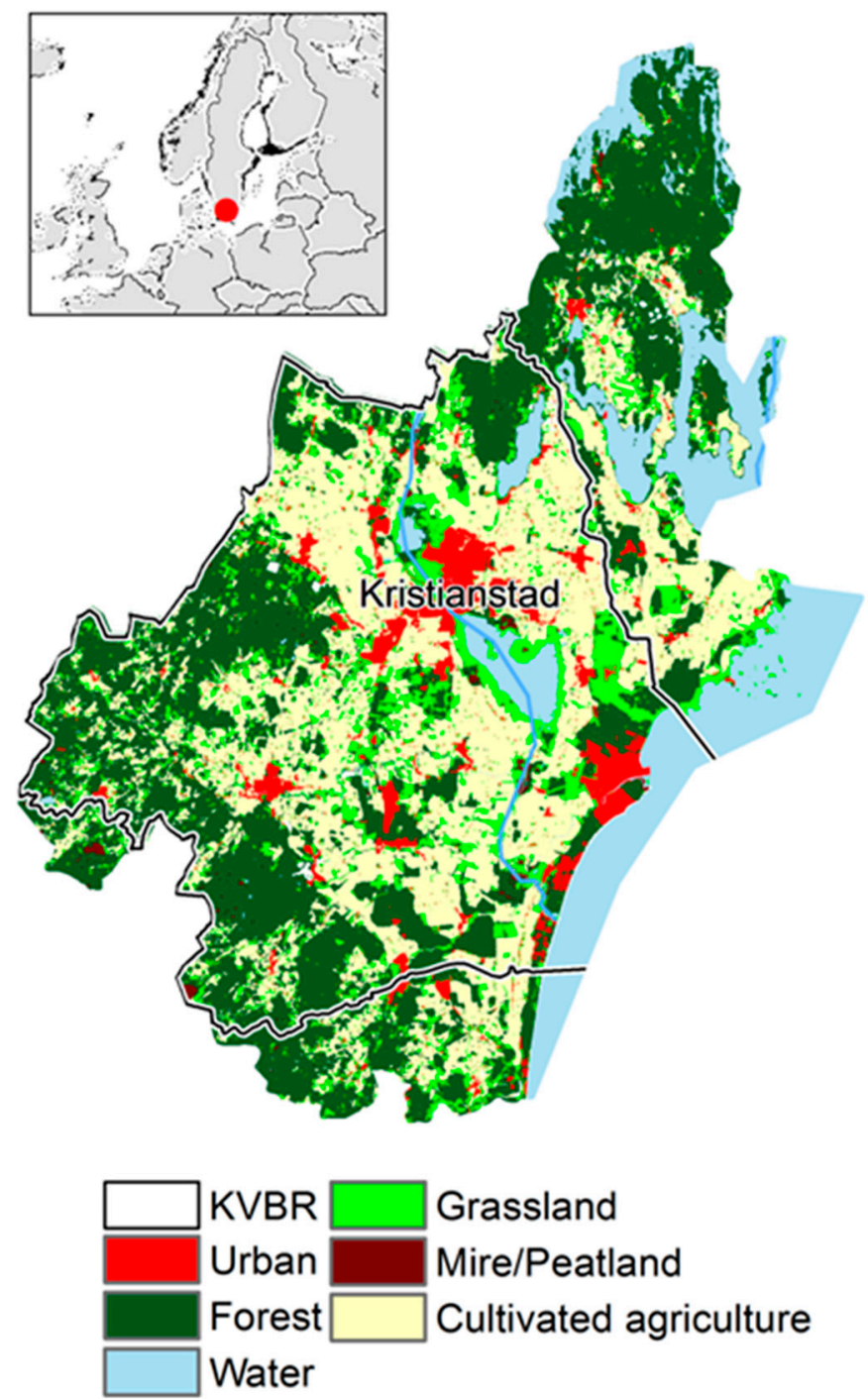

Figure 1. Map of the Kristianstad municipality study area in southernmost Sweden showing the main land covers of 2004 and the borders of the Kristianstad Vattenrike Biosphere Reserve.

To understand the historic development of semi-natural grasslands as components of green infrastructure in Kristianstad, we analyzed four different sources of data: (1) Official agricultural statistics from 1927, 1932, 1937, 1944, 1951, 1956, 1961, 1971, and 1981 about land covers of Sweden summarized by parishes [28]; (2) the reconnaissance map (scale 1:20,000) made 1812-1820 for the Skåne region [29]; (3) the ordnance survey map (scale 1:50,000) made 1926-1934 for the Skåne region [30]; and (4) Swedish Land Survey land cover maps (scale 1:50,000) 2004 (Table 1) [31].

The spatial map data (data sets $2-4$ above) were integrated using ArcGIS 10.2. Because the 1812-1820 and 1926-1934 maps were a series of images, each map set was individually stitched together using Adobe Photoshop, and subsequently georeferenced using the known geographic locations of churches $>250$ years old. Next, to match the precision of land cover units of the maps, 
the land covers of each map were digitized with a 1-ha grid resolution using the land cover categories depicted in the map legend for attribution (see Table 1).

Table 1. The total pool of terms and definitions used to describe different grassland types in the Swedish Agricultural Statistics 1927-1981 [28], and on the reconnaissance map for the Skåne region from the 1812 to 1820 [29]; the ordnance survey maps from 1926 to 1934 [30]; and Swedish Land Survey data of 2004 [31].

\begin{tabular}{|c|c|c|}
\hline Data Sources & Term & Definition \\
\hline $\begin{array}{l}\text { Swedish Agricultural } \\
\text { Statistics 1927-1981 }\end{array}$ & $\begin{array}{c}\text { Slåtteräng } \\
\text { Ordnad betesäng } \\
\text { Kultiverad betesmark } \\
\text { Annan betesäng } \\
\text { Naturlig äng } \\
\text { Betesmark } \\
\text { Hagmark }\end{array}$ & $\begin{array}{c}\text { Hay meadow } \\
\text { Orderly grazing meadow } \\
\text { Cultivated pasture } \\
\text { Other grazing meadow } \\
\text { Natural meadow } \\
\text { Pasture } \\
\text { Grazed woodland }\end{array}$ \\
\hline $\begin{array}{l}\text { Reconnaissance map } \\
\quad \text { from } 1812-1820\end{array}$ & $\begin{array}{c}\text { Öppen mark } \\
\text { Mark med tuvsymboler } \\
\text { Frisk äng eller hed } \\
\text { Betat eller tillfälligt odlad mark med sandflykt } \\
\text { Permanent åker eller äng }\end{array}$ & $\begin{array}{c}\text { Open ground } \\
\text { Field with tussocks } \\
\text { Mesic grassland or heath } \\
\text { Grazed or temporarily farmed } \\
\text { land with sand erosion } \\
\text { Permanent field or meadow }\end{array}$ \\
\hline $\begin{array}{l}\text { Ordnance survey maps } \\
1926-1934\end{array}$ & $\begin{array}{c}\text { Sidvallsäng } \\
\text { Hårdvallsäng } \\
\text { Betesmark } \\
\text { Kärr som betesmark } \\
\text { Åker huvudsakligen använd som betesmark }\end{array}$ & $\begin{array}{c}\text { Wet grasslands } \\
\text { Mesic grassland } \\
\text { Pasture } \\
\text { Fen as grazed land } \\
\text { Field mainly used as pasture }\end{array}$ \\
\hline $\begin{array}{l}\text { Swedish Land Survey } \\
\text { data } 2004\end{array}$ & $\begin{array}{c}\text { Betesmark } \\
\text { Naturlig gräsmark } \\
\text { Limnogena våtmarker }\end{array}$ & $\begin{array}{c}\text { Pasture } \\
\text { Natural grassland } \\
\text { Fen }\end{array}$ \\
\hline
\end{tabular}

\subsection{Loss of Grassland Area}

To measure the historical range of variability of the total amount of grasslands, we calculated the changes over time using the three digitized spatially explicit data sets representing 1812-1820, 1926-1934, and 2004. To validate the spatial data, we also calculated total grassland loss using official agricultural statistical data (1927-1981). Loss was defined as the complete change in grassland, i.e., the conversion of grassland to forest or to agricultural land in two steps (1812-1820 to 1926-1934, and 1926-1934 to 2004). The results were summarized for three landscape strata in the gradient from infield with agricultural land and grasslands to outfield-dominated areas with grasslands and grazed forest [32], viz. (1) forest landscapes (skogsbygd), (2) the transitional zone between forest and agricultural land (mellanbygd), and (3) agricultural land (slättbygd) [28]. This involved extracting all the various kinds of grassland data presented at the scale of parishes $(\mathrm{N}=35)$ for Kristianstad, and calculating the changes of the total amount of grasslands. Although parish borders may have changed over time, the landscape strata and their areas used in this study remained constant.

\subsection{Alteration of Grasslands}

Treating all grassland patches as equal contributors to a functional green infrastructure ignores the fact that species require different types of grasslands as habitats. Thus, to understand how the functionality of green infrastructure has developed, the effects of grassland alteration and fragmentation also need to be considered for grassland types that represent the traditional cultural landscape, i.e., semi-natural grasslands. We define semi-natural grassland as permanent unfertilized pastures or meadows formed by traditional agricultural methods. Alteration is defined as the change in grassland from one type to another based on the definitions in Table 1. First, as a proxy of cultural landscape authenticity, we analyzed the terminology describing semi-natural and other grasslands 
used in all the data, and summarized this as changes in the number of terms used over time. We thus identified changes in grassland terminology as a proxy of changes in grassland management and use. Secondly, we analyzed the area of semi-natural grasslands reported in the statistical data (1927-1976) using the three different landscape strata: (1) forest, (2) the transitional zone between forest and agricultural lowlands, and (3) agricultural lowland. Due to a lack of detail in reporting in the agricultural statistics for 1981 this year could not be analyzed (i.e., the total area of grasslands was reported, but the difference between cultivated versus not cultivated grasslands was not distinguished).

\subsection{Fragmentation of Grassland Areas}

To further understand the consequences of land use and management change on semi-natural grassland as a green infrastructure, we analyzed the changes in patch size distribution using the three spatial data sets from 1812-1820, 1926-36, and 2004. Using the umbrella species approach, namely that the presence of certain species can indicate that habitat requirements are satisfied also for other less demanding species [12], the patch size requirements of grassland wader birds (Charadrii) and game birds (Tetraonidae and Phasianidae) can be used to assess if benchmark conditions are satisfied or not. Black-tailed godwit (Limosa limosa), Curlew (Numenius arquata), Partridge (Perdix perdix), and Black grouse (Tetrao tetrix), once common in the open grassland and grassland-heath land covers in our study area, are relevant examples. The approximate minimum area requirements to support local occurrence of these species is $50-100$ ha of semi-natural grasslands [17,33]. This patch size is consistent with the observation that grassland patches of $>100$ ha also support other grassland species [34]. To assess how the total area of semi-natural grassland is distributed among different patch size intervals, we applied a geometric patch distribution of $0-25,26-50,51-100,101-200,201-400$, and $>400$ ha. We used this approach to estimate the level of semi-natural grassland fragmentation in Kristianstad. The proportion of semi-natural grassland patches exceeding 100 ha (i.e., the approximate minimum area requirement for grassland umbrella bird species) would thus reflect the amount of habitat that contributes to a functional green infrastructure of this kind.

\subsection{Cumulative Effects}

Summing up the effects of loss, alteration, and fragmentation illustrates the importance of considering the cumulative effect on the functionality grasslands as one type of green infrastructure (c.f., [35]). We estimated the cumulative effect of grassland loss, alteration, and fragmentation by multiplying the proportions of remaining semi-natural grassland between (A) the spatial data of 1812-20 and 1926-1934, (B) spatial data of 1926-1934 and 2004, (C) the Swedish statistical data of 1927-1976, and (D) the proportion of patches $>100$ ha (1812-2004) that can support a population of the most demanding grassland focal species.

\section{Results}

\subsection{Grassland Loss}

The absolute change in total grassland area within Kristianstad differed considerably among the three landscape strata. Firstly, the Swedish Agricultural Statistics (1927-1981) showed the biggest decline (54\%) of grassland within the dominating transitional landscape stratum, followed by a loss of $50 \%$ in the forest landscape stratum. The grassland proportions within the agricultural lowland remained relatively stable with a $20 \%$ loss (Figure 2). The map data spanning almost 200 years (1812-1820 to 1926-1934, and 1926-1934 to 2004) showed that the grasslands in the forest, transitional, and agricultural lowland landscapes declined even further, i.e., by $75 \%, 81 \%$, and $80 \%$, respectively (Figure 3). The area of semi-natural grasslands reported in the Swedish Agricultural Statistics of 1937 and the spatial data extracted from the state economic map of 1926-1934 showed a good correlation among parishes $(\mathrm{r}=0.78, \mathrm{n}=31)$. 


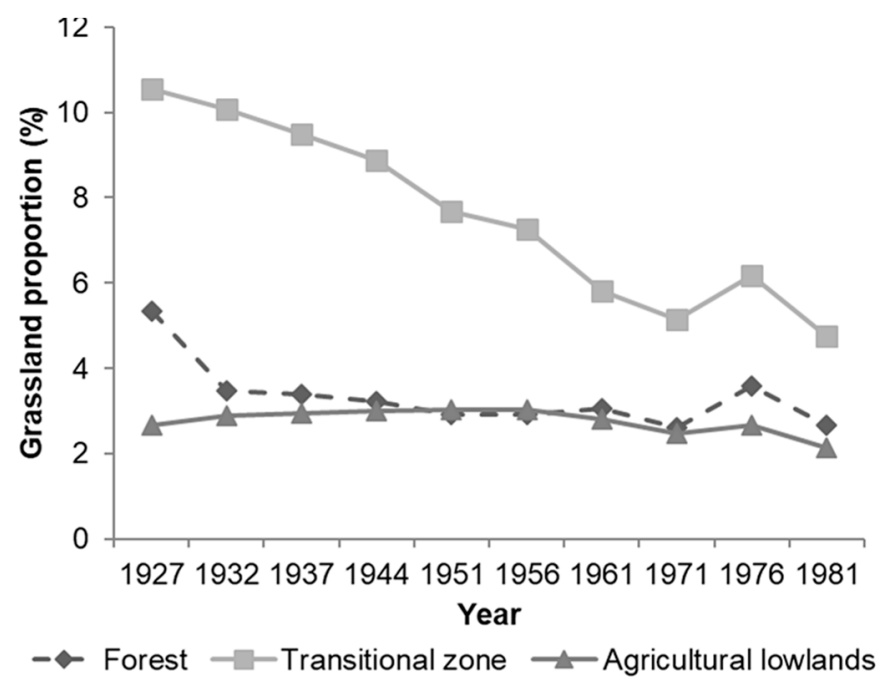

Figure 2. The area proportions of all grassland types in the Kristianstad municipality according to the Swedish Central Bureau of Statistics (1927-1981) over a 54-year period for the three landscape strata.

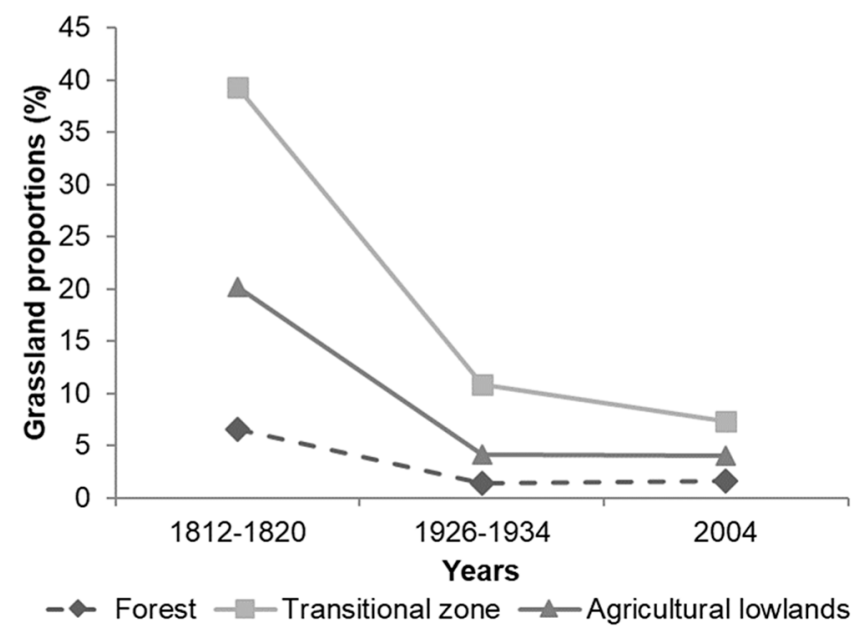

Figure 3. The area proportions of all grassland types in Kristianstad at three points in time for the three landscape strata.

\subsection{Semi-Natural Grassland Alteration}

The traditional cultural landscape based on animal husbandry utilized several management strategies to produce pastures on different kinds of grasslands (e.g., wet, dry, and wooded) [36]. Today, animal food is obtained from industrially produced agricultural crops. Indeed, the grassland terminology analysis revealed that there were many terms used in both the early day Swedish Agricultural Statistics and map sets (Table 1). The results show that over time the number of terms describing the semi-natural grasslands declined from 5 to 1 for the Swedish Agricultural Statistics (1927-1981) and 5 to 3 for the three map data sets spanning almost 200 years from 1812 to 2004 (Figure 4). This estimation using terminology as a proxy is consistent with the long-term simplification of the study area's land covers. The proportion of semi-natural grasslands of all types of grasslands declined by $41 \%$ in the forest landscape, 58\% in the transitional zone, and $59 \%$ in the agricultural lowlands over the 49-year period of 1927-1976 presented in the Swedish Agricultural Statistics (Figure 5). 


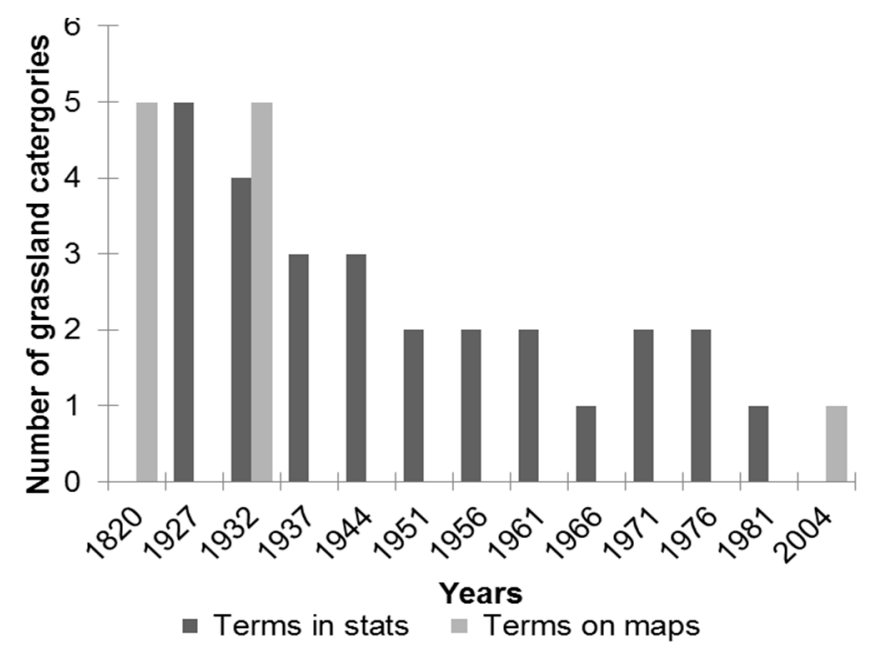

Figure 4. The number of grassland terms used from 1927 to 1981 in the Swedish Agricultural Statistics [28], the reconnaissance map for the Skåne region [29], and (2) the ordnance survey maps from 1926 to 1934 [30] and Swedish Land Survey data from 2004 [31].

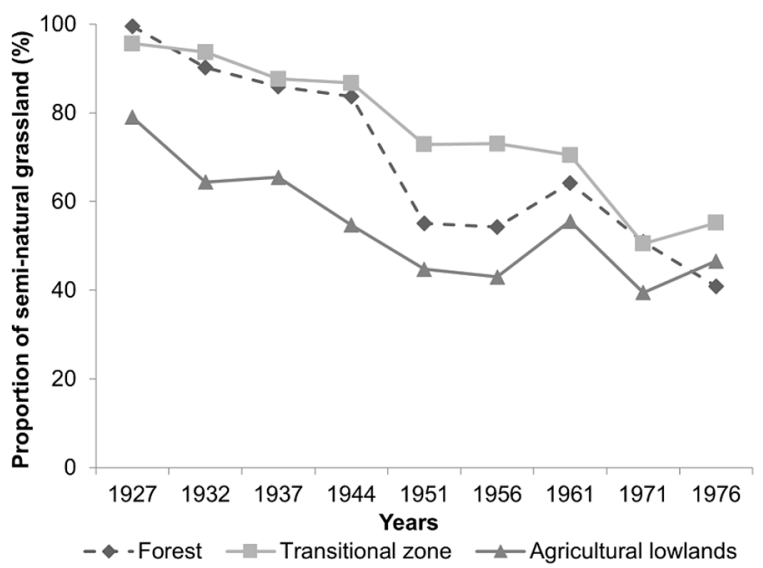

Figure 5. Temporal dynamic of the proportion of semi-natural grasslands out of all grassland types from the Swedish Agricultural Statistics of 1927-1976 in three landscape types in Kristianstad municipality. Note that the year 1981 was omitted from the alteration analysis as the grasslands were only reported as one type.

\subsection{Semi-Natural Grassland Fragmentation}

Spatial analyses of the semi-natural grasslands from the 1812-1820, 1926-1934, and 2004 maps showed the mean patch size distribution declined considerably over time (Figure 6). The area proportions of the grasslands in Kristianstad deemed large enough to support specialized umbrella bird species (i.e., >100 ha) declined by 89 to $100 \%$ in the three strata from 1812 to 2004 (Figure 7). Given the minor change of grassland patches $26-100$ ha in size and the severe loss of larger patches $>100$ ha (Figure 6), the tentative patch size threshold value of 100 ha is robust. Finally, the increase in the number of patches $0-25$ ha demonstrates the long-term fragmentation process. 


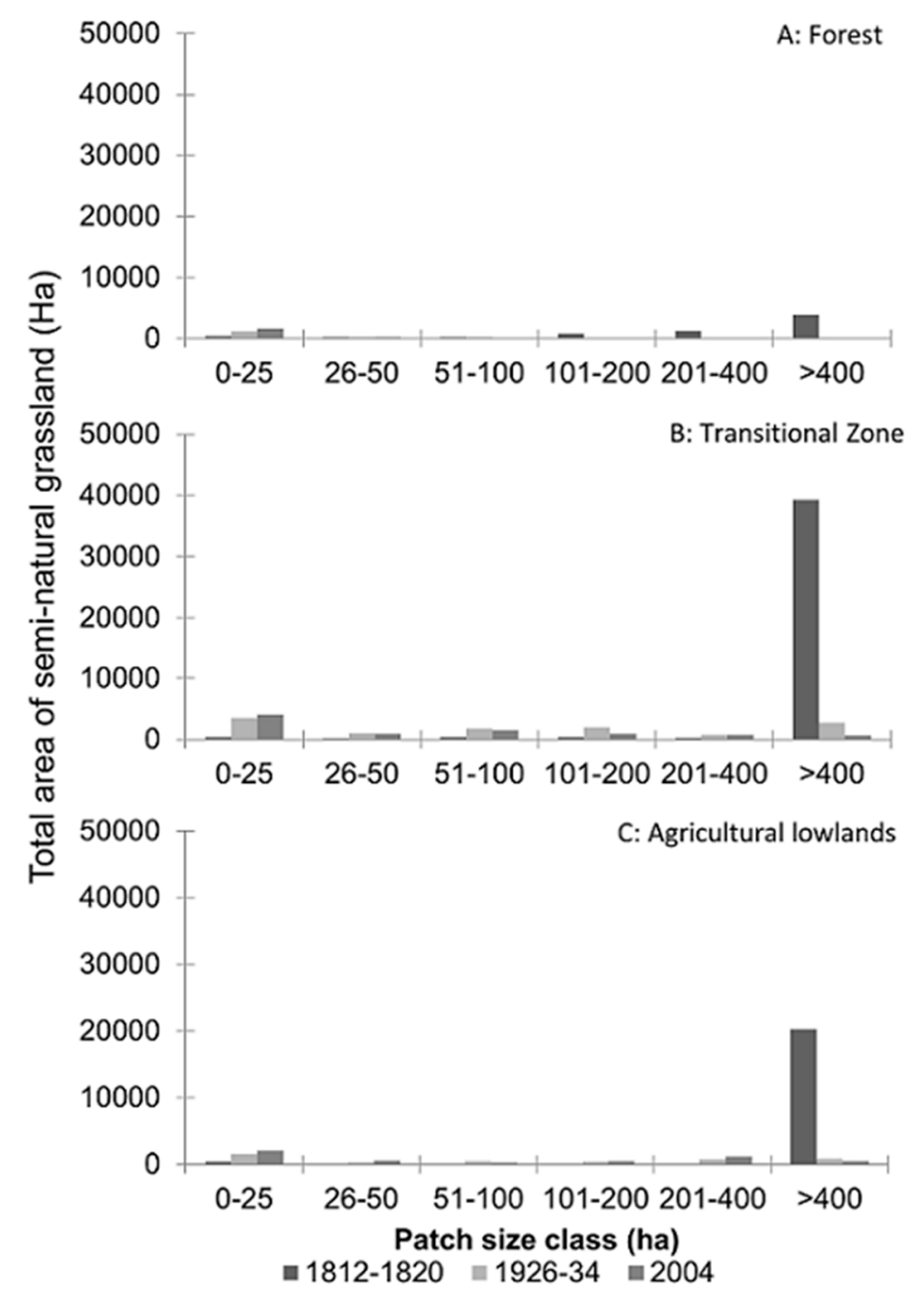

Figure 6. Graphs showing the area distribution of semi-natural grasslands among patch size classes in Kristianstad based on analyses of maps from 1812-1820, 1926-1934, and 2004 among the forest (A), transitional zone (B), and agricultural lowland (C) landscapes.

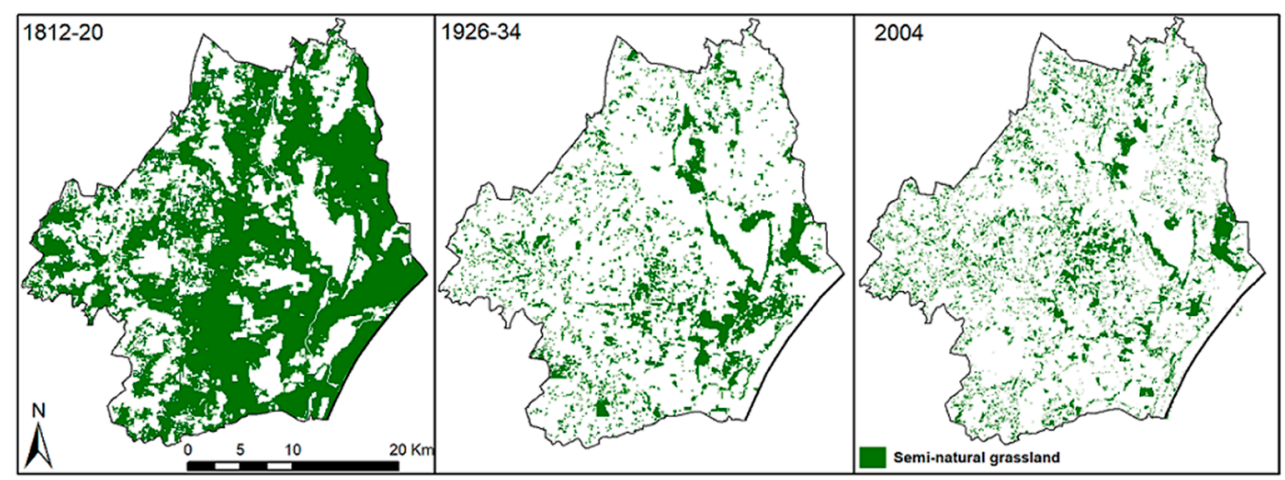

Figure 7. Three maps zoomed in on the Kristianstad Vattenrike Biosphere Reserve, showing the amount of semi-natural grasslands for the three-time periods. The maps show the loss and fragmentation of semi-natural grasslands over 2 centuries from 1812 to 2004 . 


\subsection{Cumulative Effect}

By combining the effects of loss, alteration, and fragmentation of semi-natural grassland patches over the past two centuries, we estimate that remaining functionality of the Kristianstad grasslands as a green infrastructure varies from 0 to 0.009 for the three landscape strata (Table 2).

Table 2. Estimated cumulative effect of 200 years of grassland alteration and fragmentation on habitat loss affecting the functionality of grasslands as green infrastructure.

\begin{tabular}{|c|c|c|c|}
\hline \multirow{2}{*}{ Steps in the Analysis of Cumulative Effect } & \multicolumn{3}{|c|}{$\begin{array}{l}\text { Landscape Strata in the Forest Upland to Agricultural } \\
\text { Lowland Gradient }\end{array}$} \\
\hline & Forest & Transitional Zone & Agricultural Lowland \\
\hline $\begin{array}{l}\text { (A) Remaining grasslands by comparison of } \\
\text { spatial data 1812-20 to 1926-1934 } \\
\text { (see Figure 3) }\end{array}$ & 0.22 & 0.28 & 0.21 \\
\hline $\begin{array}{l}\text { (B) Remaining grasslands by comparison of } \\
\text { spatial data 1926-1934 to } 2004 \text { (see Figure 3) }\end{array}$ & 1.15 & 0.67 & 0.97 \\
\hline $\begin{array}{l}\text { (C) Remaining proportion of semi-natural } \\
\text { grassland by comparison of 1926-1934 to } \\
1976 \text { (see Figure 5) }\end{array}$ & 0.59 & 0.42 & 0.41 \\
\hline $\begin{array}{l}\text { (D) Remaining proportion of sufficiently } \\
\text { large patches }>100 \text { ha during the last } \\
200 \text { years (Figure } 6 \text { ) }\end{array}$ & 0 & 0.06 & 0.11 \\
\hline $\begin{array}{l}\text { Cumulative effect }(\mathrm{A} \times \mathrm{B} \times \mathrm{C} \times \mathrm{D}) \text { in terms } \\
\text { of remaining semi-natural } \\
\text { grassland functionality }\end{array}$ & 0 & 0.0047 & 0.0091 \\
\hline
\end{tabular}

\section{Discussion}

\subsection{Reduced Functionality of Semi-Natural Grasslands as a Green Infrastructure}

Combining loss, alteration, and fragmentation shows that the Kristianstad grasslands have undergone considerable changes throughout the past two centuries, with a cumulative negative effect corresponding to a loss of functional green infrastructure amounting to $98-100 \%$. Natural and semi-natural grasslands can be classified into many categories, thus making it difficult to estimate the amount of grasslands that form different types of representative green infrastructure [37]. Our results demonstrate a strong simplification in terminology used to describe the grassland systems. This is consistent with the gradual disappearance of the traditional cultural landscape.

The degradation of the semi-natural grasslands of Kristianstad is linked to the declines and local extinction of several wader species (e.g., [5]). Unfortunately, data documenting wader population trends do not extend across more than three decades. However, similar declines in wader populations have been recorded over the past 150 years throughout southern Sweden [38,39] and Europe [40]. Wader population declines are associated with the intensification of grassland management leading to changes in both the patterns of land covers [40] and ecological processes [5]. The same applies to the Black grouse [41].

Similar declines in the quantity and quality of Southern Sweden's cultural wooded grasslands, under traditions of low intensity farming and animal husbandry, have been found [42,43]. The decline and extinction of middle-spotted woodpecker (Dendrocoptes medius) and saproxylic beetles are examples of the consequences of converting cultural wooded grasslands to monocultures of coniferous trees [44,45]. A similar fate has been predicted for the last remaining patches (30-50 ha in total) of Kristianstad's xeric grasslands even if low intensity farming practices, such as grazing or long rotational cultivation, are maintained, because the degradation is too widespread in an already fragmented system [46]. 
The loss, alteration, and fragmentation of grasslands in Kristianstad, one of Sweden's most prized grassland areas, are consistent with other findings of grassland degradation in Southern Sweden. The long development history of intensive forestry and agriculture in southern Sweden has reduced the quantity and quality of several grassland types including lowland wet grasslands [47], cultural wooded grasslands [42,43,48,49], and dry xeric and calcareous grasslands [46]. However, this is not limited to Sweden with similar declines found for the alvar grasslands of Estonia: $-72 \%$ from 1930 to $2008[50,51]$.

The historic range of variability increases when the timeframe is increased [24]. Extending the temporal period would also exacerbate the change in grassland loss, alteration, and fragmentation. Three factors leading to land cover change that occurred $>200$ years ago (i.e., prior to the time frame used in this study) are (1) agricultural intensification linked to land consolidation, (2) the planting of trees and forest to stop erosion and the shifting of the sand dunes, and (3) the lowering of the surface water table of the Helge å River by changing its natural course to the Baltic Sea in 1774 [52]. In addition, Christensen [14] reported that about only $1 / 5$ to $1 / 6$ of the Kristianstad grasslands were under plough 1000 years prior to the 1880s. Therefore, the area of grassland habitats as functional green infrastructure may have declined further than found in this study. Kristianstad's xeric sand steppe was once large enough to host a local population of the Great bustard (Otis tarda) up until the mid-19th century $[53,54]$.

The time for species to respond to habitat degradation and fragmentation can be very long [55]. This slow effect means the local extinction debt of other species reliant on the plant communities can be even slower. A good example of this is the high species richness and high grassland indicator species found after the first forest rotation harvest ( 80 years since planting) of converted historic grasslands [56].

Thus, the switch from low intensity traditional farming to intensive farming has affected many animal and plant species dependent on semi-natural grasslands [22,36,57,58]. Loss, alteration, and fragmentation of semi natural grassland patches in Southern Sweden $[59,60]$, and thus reduced functionality of semi-natural grasslands as green infrastructure, are linked to losses in species richness [61,62]. However, evidence indicates that the abundance and breeding success of bird species are dependent on both the patterns within their biophysical land cover patch (e.g., [63]) and the processes within the surrounding landscape's matrix [64]. For example, avian predator abundance and predation rates of ground nesting birds have been shown to affect their composition and abundance [5,65]. The removal of predators [66] and provision of alternative food [67] has been shown to positively affect the reproductive success of ground nesting birds.

To conclude, landscape transformation has changed two key interrelated aspects related to habitats: patterns and processes [68]. Patterns involve the loss, alteration, and fragmentation of semi-natural grassland, which have negatively affected landscape processes (e.g., [36]), habitat structure (e.g., [69]), and specialized species (e.g., [70]). Processes include reduced connectivity of patches [71], altered hydrology [72] and edge effects in terms of increased predation [73], which all need to be considered in the restoration of semi-natural grasslands as a functional green infrastructure, and in the surrounding matrix. A follow up to this study would be to analyze the relative importance of patterns and processes both inside habitat networks and the surrounding landscape matrix.

\subsection{Combining Historical Ecology and Evidenced-Knowledge about What Species Require}

The approach to combine historical ecology and analyzing maps and statistical data to estimate the magnitudes and trajectories of grassland habitat changes on the one hand, and species patch area requirements on the other, shows that the benchmark for landscape restoration depends on timeframe used as a reference point (Figure 8). Historical maps represent an extremely valuable and under-used data repository that can provide an insight into types and amounts of past land covers. Using historical maps to trace land cover change is an effective way to compliment and provide greater knowledge on 
the restoration of habitats [74]. Indeed, many of Sweden's old land cover maps such as those used in this study have been deemed suitable and used to explore land cover change in Sweden $[49,60]$.

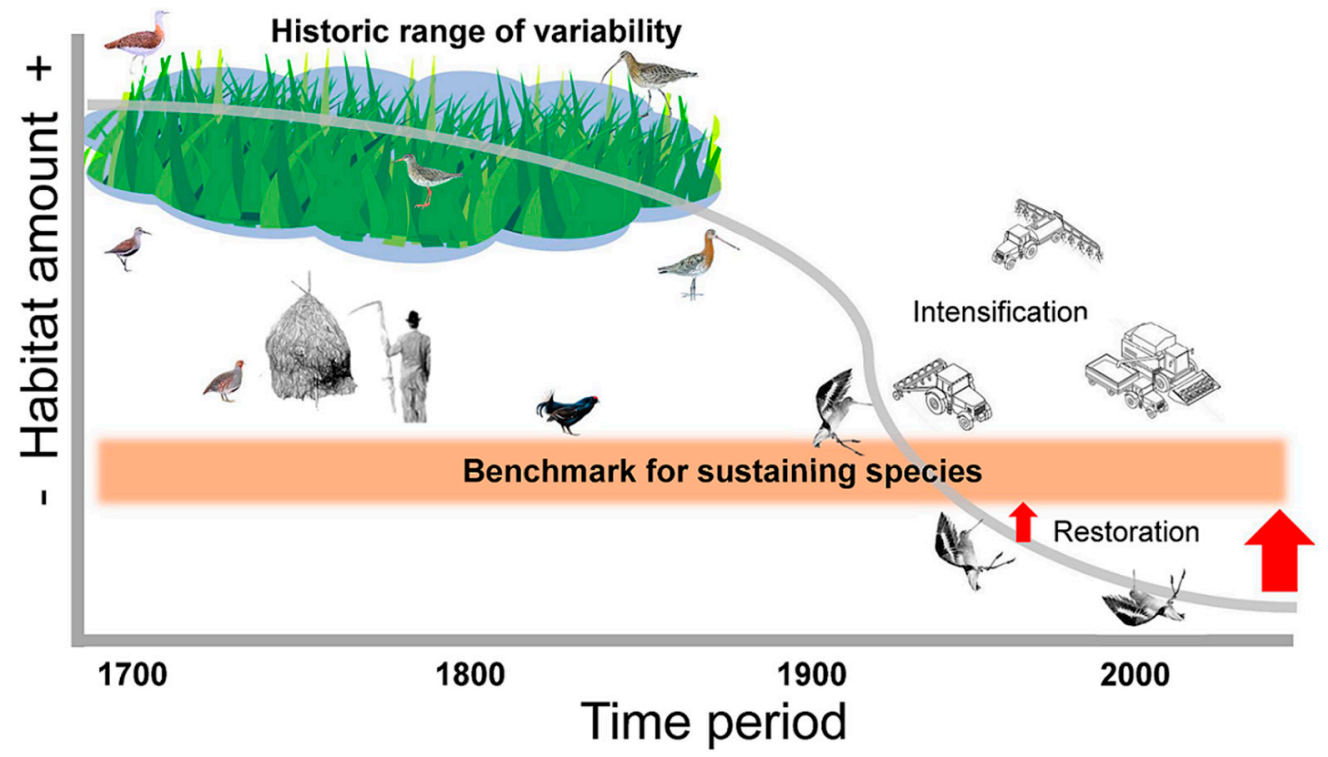

Figure 8. Summary of how data on the historic range of variability of a particular land cover and evidence-based knowledge about threshold interval for local extinction due to habitat loss [75] can be combined to derive benchmarks as targets for landscape restoration and spatial planning towards a functional green infrastructure. The grassland cloud at the top represents the range of historical variability. The benchmark area illustrates the proportion of the historical range of variability that forms the benchmark level required for ecological sustainability. The grey line indicates the change over time in the amount of semi-natural grassland within Kristianstad. Finally, the arrows represent the need for landscape restoration and the need for pro-active spatial planning towards land-sparing. This study exemplifies this general approach using semi-natural grasslands and avian umbrella species. Illustration by M. Manton.

Regional gap analysis is a method that strategically assesses the natural/historic vs. current amounts of representative land covers to maintain natural occurring species in a region (e.g., [76,77]). Angelstam and Andersson [10] and Lõhmus, et al. [78] used the emerging empirical knowledge about how much habitat umbrella species need to maintain functional habitat networks to conserve viable populations. Next, to secure green infrastructure functionality, tactical spatial planning is needed. Habitat suitability modelling using spatially explicit land cover data with sufficient thematic resolution is one example [79].

\subsection{Green Infrastructure and Human Well-Being}

Grasslands provide a range of ecosystem services and benefits for human well-being [80]. Although the emphasis of this study is placed on the ecological sustainability of grassland conservation, the Kristianstad landscape is ultimately managed and governed to achieve a balance between ecological, economic, and social dimensions of sustainability. The loss, alteration, and fragmentation of grasslands for biodiversity may also lead to losses of other ecosystem benefits or services, such as hydrological regulation, cultural heritage, carbon sequestration, and functioning ecosystems. Although this study shows a dramatic loss of the area of semi-natural grasslands, as well as alteration and fragmentation, the grasslands nevertheless deliver benefits to humans $[81,82]$.

Due to degradation of grasslands as one type of green infrastructure, landscape restoration initiatives have been implemented. Land ownership is divided into many small farming units for each grassland patch; therefore, spatial planning needs to encourage collaboration of land owners 
and stakeholders from different sectors at multiple levels in the social systems to improve sustainable development processes in terms of societal steering [83] and social learning [84]. This has occurred both locally in Kristianstad and partly in the entire catchment of the Helge å River [82,85]. Unfortunately, attempts to restore grasslands have only resulted in short term results [5]. A shortcoming is the lack of understanding of the tremendous declines in grasslands as a functional green infrastructure compared to the historic range of variability. Today sufficiently large unfragmented patches with appropriate quality are not large enough to sustain focal grassland birds. In addition, cultural landscapes such as semi-natural grasslands require ongoing maintenance. Thus, the deficiency of long-term funding for sustained management will undercut attempts to conserve functional grassland habitat networks. Currently in southern Sweden the remaining grasslands only receive short-term environmental subsidies programs to maintain livestock grazing and mowing at a small scale [86]. This shows that grasslands are not a functional green infrastructure. In addition, intricate landownership patterns and relations add further complexity that needs to be considered as land owners often have very different land management objectives.

\subsection{The Need for Spatial Planning}

Implementing policy about green infrastructure requires evidence-based cross-sectoral collaboration and regional adaptation. This means that well-informed social innovations need to be encouraged in landscapes as social-ecological systems [87]. The Kristianstad Vattenrike Biosphere Reserve governance system has been deemed a social success story $[88,89]$. However, the conservation status of its priority semi-natural grassland ecosystems is still unfavorable $[5,46]$. Maintaining semi-natural grasslands as green infrastructure is more than just about land cover [5]. Their management needs to involve many factors at multiple spatial scales. Thus, functional habitat networks are not only about patch quality and size linked to land cover characteristics, but also about other processes, such as hydrology, trophic interactions (i.e., predation), and climate change, as well as the diversity of land uses associated with traditional practices. This requires a two-pronged approach involving both governance levels and multiple spatial scales.

First, a comprehensive understanding of the social-ecological systems that created the semi-natural grasslands is needed to aid in producing knowledge about area protection, conservation management, the delivery of multiple products and services, and landscape restoration for both biodiversity conservation and human well-being. The most important values of grasslands are co-generated by interacting social and ecological systems. Therefore, re-wilding strategies may not be suitable to safeguard the full range of biodiversity and multiple products in semi-natural grasslands [90]. The multi-functionality of semi-natural grasslands suggests that fostering multiple types of traditional land use may be a promising management strategy. Specific agro-environmental schemes should be developed to avoid abandonment and support management that addresses the delivery of multiple products, including the maintenance of cultural values at the same time. Bio-cultural values (e.g., animal husbandry, traditional hay making, and grazing) are one of the 'key products' of semi-natural grasslands, but current land management strategies do not address these values. Thus, land management and governance should be developed with a better awareness of bio-cultural values [91]. The implementation of specific policy instruments to financially support land managers to supply values to society represents a future challenge that both research and policy makers should focus upon [90].

Second, both anthropogenic and natural processes from individual land cover patches through to landscape and regions need to be understood. Hence, the conservation of semi-natural grasslands as functional green infrastructure is complex and requires continuous knowledge production and learning, as well as ongoing maintenance and monitoring programs to assess consequences on the ground [92]. One approach to enhance collaborative learning among researchers and stakeholders is to use multiple landscapes as case studies $[5,93]$. Such case study landscapes should vary in size, habitat type and quality, and species assemblages and portfolios of processes linked to landscape 
history, as well as landscape stewardship and management approaches that include grasslands with both unfavorable and favorable conservation status. To cover the entire gradient from agricultural lowlands to forest this study focused on multiple datasets, e.g., military and economic maps as well as official agricultural statistics. Therefore, learning about the historical range of variability using various types and amounts of semi-grasslands can be enhanced by triangulation using methods from historical ecology and cadastral maps [55], archaeology, ethnology, and anthropology [94], as well as spatial modelling using topography, soil richness, and wetness. Therefore, transdisciplinary research through collaboration among natural and social scientists and practitioners of traditional management practices is needed to develop strategies for holistic sustainable management of grasslands in different contexts.

Acknowledgments: This study was made with funding from the Swedish Research Council FORMAS (grant number 2011-1737) to Per Angelstam. We thank Marine Elbakidze, Are Kont, and three anonymous reviewers for valuable comments on the manuscript.

Author Contributions: M.M. and P.A. conceived, designed the experiments, performed the experiments, analyzed the data, and wrote the paper equally.

Conflicts of Interest: The authors declare no conflict of interest. The founding sponsors had no role in the design of the study; in the collection, analyses, or interpretation of data; in the writing of the manuscript; or in the decision to publish the results.

\section{References}

1. Costanza, R.; Daly, H.E. Natural capital and sustainable development. Conserv. Biol. 1992, 6, 37-46. [CrossRef]

2. Petrosillo, I.; Zaccarelli, N.; Zurlini, G. Multi-scale vulnerability of natural capital in a panarchy of social-ecological landscapes. Ecol. Complex. 2010, 7, 359-367. [CrossRef]

3. Brumelis, G.; Jonsson, B.G.; Kouki, J.; Kuuluvainen, T.; Shorohova, E. Forest naturalness in northern Europe: Perspectives on processes, structures and species diversity. Silva Fenn. 2011, 45, 807-821. [CrossRef]

4. Hartel, T.; Plieninger, T. European Wood-Pastures in Transition: A Social-Ecological Approach; Routledge: London, UK, 2014.

5. Manton, M.; Angelstam, P.; Milberg, P.; Elbakidze, M. Wet grasslands as a green infrastructure for ecological sustainability: Wader conservation in southern Sweden as a case study. Sustainability 2016, 8, 340. [CrossRef]

6. Tzoulas, K.; Korpela, K.; Venn, S.; Yli-Pelkonen, V.; Kaźmierczak, A.; Niemela, J.; James, P. Promoting ecosystem and human health in urban areas using green infrastructure: A literature review. Landsc. Urban Plan. 2007, 81, 167-178. [CrossRef]

7. Angelstam, P.; Khaulyak, O.; Yamelynets, T.; Mozgeris, G.; Naumov, V.; Chmielewski, T.J.; Elbakidze, M.; Manton, M.; Prots, B.; Valasiuk, S. Green infrastructure development at European Union's eastern border: Effects of road infrastructure and forest habitat loss. J. Environ. Manag. 2017, 193, 300-311. [CrossRef] [PubMed]

8. Jongman, R.H.G. Nature conservation planning in Europe: Developing ecological networks. Landsc. Urban Plan. 1995, 32, 169-183. [CrossRef]

9. Čivić, K.; Jones-Walters, L.M. Implementing green infrastructure and ecological networks in Europe: Lessons learned and future perspectives. J. Green Eng. 2014, 4, 307-324.

10. Angelstam, P.; Andersson, L. Estimates of the needs for forest reserves in Sweden. Scand. J. For. Res. 2001, 16, 38-51. [CrossRef]

11. Andersson, K.; Angelstam, P.; Elbakidze, M.; Axelsson, R.; Degerman, E. Green infrastructures and intensive forestry: Need and opportunity for spatial planning in a Swedish rural-urban gradient. Scand. J. For. Res. 2013, 28, 143-165. [CrossRef]

12. Roberge, J.-M.; Angelstam, P. Usefulness of the umbrella species concept as a conservation tool. Conserv. Biol. 2004, 18, 76-85. [CrossRef]

13. European Commission. Green Infrastructure (GI)_Enhancing Europe's Natural Capital; Communication from the Commission to the European Parliament, the Council, the European Economic and Social Committee and the Committee of the Regions; European Commission: Brussels, Belgium, 2013.

14. Christensen, C. Agrarhistoriske Studier; Schubothe: Copenhagen, Denmark, 1886; Volume 2.

15. Cramer, V.A.; Hobbs, R.J.; Standish, R.J. What's new about old fields? Land abandonment and ecosystem assembly. Trends Ecol. Evol. 2008, 23, 104-112. [CrossRef] [PubMed] 
16. Keane, R.E.; Hessburg, P.F.; Landres, P.B.; Swanson, F.J. The use of historical range and variability (hrv) in landscape management. For. Ecol. Manag. 2009, 258, 1025-1037. [CrossRef]

17. Angelstam, P.; Dönz-Breuss, M.; Roberge, J.-M. Targets and tools for the maintenance of forest biodiversity: An introduction. Ecol. Bull. 2004, 51, 11-24.

18. Lindenmayer, D.B.; Fischer, J. Habitat Fragmentation and Landscape Change: An Ecological and Conservation Synthesis; Island Press: Washington, DC, USA, 2006; p. 329.

19. Plieninger, T. Habitat loss, fragmentation, and alteration-Quantifying the impact of land-use changes on a Spanish Dehesa landscape by use of aerial photography and GIS. Landsc. Ecol. 2006, 21, 91-105. [CrossRef]

20. Myrdal, J.; Morell, M. The Agrarian History of Sweden; Nordic Academic Press: Lund, Sweden, 2011.

21. Eriksson, O.; Cousins, S. Historical landscape perspectives on grasslands in Sweden and the Baltic region. Land 2014, 3, 300. [CrossRef]

22. Price, E. Lowland Grassland and Heathland Habitats; Routledge: London, UK, 2003.

23. European Commission. Report on the Status of and Trends for Habitat Types and Species Covered by the Birds and Habitats Directives for the 2007-2012 Period as Required under Article 17 of the Habitats Directive and Article 12 of the Birds Directive; Report from the Commission to the Council and the European Parliament; The State of Nature in the European Union; European Commission: Brussels, Belgium, 2015.

24. Egan, D.; Howell, E. The Historical Ecology Handbook. A Restorationist's Guide to Reference Ecosystem; Island Press: Washington, DC, USA, 2001.

25. Lagerås, P. Medieval colonisation and abandonment in the south Swedish uplands: A review of settlement and land use dynamics inferred from the pollen record. Archaeol. Balt. 2013, 20, 77-90. [CrossRef]

26. Richnau, G.; Angelstam, P.; Valasiuk, S.; Zahvoyska, L.; Axelsson, R.; Elbakidze, M.; Farley, J.; Jönsson, I.; Soloviy, I. Multifaceted value profiles of forest owner categories in South Sweden: The river Helge å catchment as a case study. AMBIO 2013, 42, 188-200. [CrossRef] [PubMed]

27. Magnusson, S.-E.; Magntorn, K.; Wallsten, E.; Cronert, H.; Thelaus, M. Kristianstads Vattenrike Biosphere Reserve Nomination Form; Kristianstad Kommun: Kristianstad, Sweden, 2004.

28. Statistics, S.C.B.O. Official Statistics of Sweden: Census of Agriculture-from 1927 to 1981; Statistika Centralbyran: Stockholm, Sweden, 1983.

29. Lantmäteriet. Skånska Rekognosceringskartan 1812-1820; Lantmäteriet: Stockholm, Sweden, 1986.

30. Swedish Economic Department. Ordanance Survey 1926-1934 (Scale 1:20,000); Kristianstad County Agricultural Society: Kristianstad, Sweden, 1936.

31. Lantmäteriet. Tematisk Noggrannhe i Svenska Marcktäckedata; Lantmäteriet: Stockholm, Sweden, 2004.

32. Mikusiński, G.; Angelstam, P.; Sporrong, U. Distribution of deciduous stands in villages located in coniferous forest landscapes in Sweden. AMBIO 2003, 32, 520-526. [CrossRef] [PubMed]

33. Cramp, S. Handbook of the Birds of Europe the Middle East and North Africa: The Birds of the Western Palearctic: 3. Waders to Gulls; Oxford University Press: Oxford, UK, 1990.

34. Rannap, R.; Kaart, T.; Pehlak, H.; Kana, S.; Soomets, E.; Lanno, K. Coastal meadow management for threatened waders has a strong supporting impact on meadow plants and amphibians. J. Nat. Conserv. 2017, 35, 77-91. [CrossRef]

35. Haddad, N.M.; Brudvig, L.A.; Clobert, J.; Davies, K.F.; Gonzalez, A.; Holt, R.D.; Lovejoy, T.E.; Sexton, J.O.; Austin, M.P.; Collins, C.D.; et al. Habitat fragmentation and its lasting impact on earth's ecosystems. Sci. Adv. 2015, 1, e1500052. [CrossRef] [PubMed]

36. Joyce, C.; Wade, P. Wet Grasslands: A European Perspective; John Wiley: Chichester, UK, 1998; p. 340.

37. Ihse, M.; Lindahl, C. A holistic model for landscape ecology in practice: The Swedish survey and management of ancient meadows and pastures. Landsc. Urban Plan. 2000, 50, 59-84. [CrossRef]

38. Nilsson, S. Skandinavisk Fauna; Foglarna. Första Bandet; Gleerups: Lund, Sweden, 1858.

39. Ottvall, R.; Edenius, L.; Elmberg, J.; Engström, H.; Green, M.; Holmqvist, N.; Lindström, Å.; Pärt, T.; Tjernberg, M. Population trends for Swedish breeding birds. Ornis Svec. 2009, 19, 117-192.

40. Thorup, O. Breeding Waders in Europe 2000; International Wader Study Group: Devon, UK, 2005; Volume 14, p. 142.

41. Angelstam, P.; Runfors, O.; Mikusinski, G.; Seiler, C. Long-term dynamics of three types of black grouse habitat in the centre and at the edge of the distribution range in Sweden 1850-2000. Cah. d'Ethol. 2000, 20, 165-190. 
42. Bergman, K.-O.; Ask, L.; Askling, J.; Ignell, H.; Wahlman, H.; Milberg, P. Importance of boreal grasslands in Sweden for butterfly diversity and effects of local and landscape habitat factors. Biodivers. Conserv. 2008, 17, 139-153. [CrossRef]

43. Brunet, J.; Felton, A.; Lindbladh, M. From wooded pasture to timber production-Changes in a European beech (Fagus sylvatica) forest landscape between 1840 and 2010. Scand. J. For. Res. 2012, 27, 245-254. [CrossRef]

44. Ekberg, B.; Nilsson, L. Skånes Fåglar Idag och i Gången tid; Signum: Lund, Sweden, 1994.

45. Bergman, K.-O.; Jansson, N.; Claesson, K.; Palmer, M.W.; Milberg, P. How much and at what scale? Multiscale analyses as decision support for conservation of saproxylic oak beetles. For. Ecol. Manag. 2012, 265, 133-141. [CrossRef]

46. Ödman, A.M.; Olsson, P.A. Conservation of sandy calcareous grassland: What can be learned from the land use history? PLoS ONE 2014, 9, e90998. [CrossRef] [PubMed]

47. Cousins, S.A.O.; Eriksson, Å.; Franzén, D. Reconstructing past land use and vegetation patterns using palaeogeographical and archaeological data: A focus on grasslands in Nynäs by the Baltic Sea in south-eastern Sweden. Landsc. Urban Plan. 2002, 61, 1-18. [CrossRef]

48. Lindbladh, M.; Axelsson, A.-L.; Hultberg, T.; Brunet, J.; Felton, A. From broadleaves to spruce-The borealization of southern Sweden. Scand. J. For. Res. 2014, 29, 686-696. [CrossRef]

49. Cousins, S.A.O.; Auffret, A.G.; Lindgren, J.; Tränk, L. Regional-scale land-cover change during the 20th century and its consequences for biodiversity. AMBIO 2015, 44, 17-27. [CrossRef] [PubMed]

50. Laasimer, L. Eesti NSV taimkate. In Estonian with Russian and English Summaries; Valgus: Tallinn, Estonia, 1965.

51. Helm, A.; Zobel, M.; Moles, A.T.; Szava-Kovats, R.; Pärtel, M. Characteristic and derived diversity: Implementing the species pool concept to quantify conservation condition of habitats. Divers. Distrib. 2015, 21, 711-721. [CrossRef]

52. Sjöbeck, M. Det Sydsvenska Landskapets Historia och vård; AB Landstryck: Landskrona, Sweden, 1973.

53. Bengtsson, K. Stortrappens skånska historia-En parentes? Anser 2015, 1, 21-38.

54. Bengtsson, K. Stortrapp-Tillägg och rättelser. Anser 2015, 3, 45.

55. Lindborg, R.; Eriksson, O. Historical landscape connectivity affects present plant species diversity. Ecology 2004, 85, 1840-1845. [CrossRef]

56. Jonason, D.; Ibbe, M.; Milberg, P.; Tunér, A.; Westerberg, L.; Bergman, K.-O. Vegetation in clear-cuts depends on previous land use: A century-old grassland legacy. Ecol. Evol. 2014, 4, 4287-4295. [CrossRef] [PubMed]

57. Schneider, C.; Fry, G. Estimating the consequences of land-use changes on butterfly diversity in a marginal agricultural landscape in Sweden. J. Nat. Conserv. 2005, 13, 247-256. [CrossRef]

58. Ö̈kinger, E.; Bergman, K.-O.; Franzén, M.; Kadlec, T.; Krauss, J.; Kuussaari, M.; Pöyry, J.; Smith, H.G.; Steffan-Dewenter, I.; Bommarco, R. The landscape matrix modifies the effect of habitat fragmentation in grassland butterflies. Landsc. Ecol. 2012, 27, 121-131. [CrossRef]

59. Cousins, S.A.O.; Ohlson, H.; Eriksson, O. Effects of historical and present fragmentation on plant species diversity in semi-natural grasslands in Swedish rural landscapes. Landsc. Ecol. 2007, 22, 723-730. [CrossRef]

60. Lindborg, R.; Bengtsson, J.; Berg, Å.; Cousins, S.A.O.; Eriksson, O.; Gustafsson, T.; Hasund, K.P.; Lenoir, L.; Pihlgren, A.; Sjödin, E.; et al. A landscape perspective on conservation of semi-natural grasslands. Agric. Ecosyst. Environ. 2008, 125, 213-222. [CrossRef]

61. Cousins, S.A.O.; Eriksson, O. After the hotspots are gone: Land use history and grassland plant species diversity in a strongly transformed agricultural landscape. Appl. Veg. Sci. 2008, 11, 365-374. [CrossRef]

62. Ekroos, J.; Rundlöf, M.; Smith, H.G. Trait-dependent responses of flower-visiting insects to distance to semi-natural grasslands and landscape heterogeneity. Landsc. Ecol. 2013, 28, 1283-1292. [CrossRef]

63. Wrbka, T.; Erb, K.-H.; Schulz, N.B.; Peterseil, J.; Hahn, C.; Haberl, H. Linking pattern and process in cultural landscapes. An empirical study based on spatially explicit indicators. Land Use Policy 2004, 21, 289-306. [CrossRef]

64. Berg, Å.; Wretenberg, J.; Żmihorski, M.; Hiron, M.; Pärt, T. Linking occurrence and changes in local abundance of farmland bird species to landscape composition and land-use changes. Agric. Ecosyst. Environ. 2015, 204, 1-7. [CrossRef]

65. Angelstam, P. Predation on ground-nesting birds' nests in relation to predator densities and habitat edge. Oikos 1986, 47, 365-373. [CrossRef] 
66. Kauhala, K.; Helle, P.; Helle, E. Predator control and the density and reproductive success of grouse populations in finland. Ecography 2000, 23, 161-168. [CrossRef]

67. Lindström, E.; Angelstam, P.; Widén, P.; Andrén, H. Do predators synchronize vole and grouse fluctuations? An experiment. Oikos 1987, 48, 121-124. [CrossRef]

68. Turner, M.G. Landscape ecology: The effect of pattern on process. Annu. Rev. Ecol. Syst. 1989, 20, 171-197. [CrossRef]

69. Angelstam, P.; Dönz-Breuss, M. Measuring forest biodiversity at the stand scale: An evaluation of indicators in European forest history gradients. Ecol. Bull. 2004, 51, 305-332.

70. Devictor, V.; Julliard, R.; Jiguet, F. Distribution of specialist and generalist species along spatial gradients of habitat disturbance and fragmentation. Oikos 2008, 117, 507-514. [CrossRef]

71. Eglington, S.M.; Gill, J.A.; Smart, M.A.; Sutherland, W.J.; Watkinson, A.R.; Bolton, M. Habitat management and patterns of predation of northern lapwings on wet grasslands: The influence of linear habitat structures at different spatial scales. Biol. Conserv. 2009, 142, 314-324. [CrossRef]

72. Brennan, L.A.; Kuvlesky, W.P., Jr. North American grassland birds: An unfolding conservation crisis? J. Wildl. Manag. 2005, 69, 1-13. [CrossRef]

73. Andrén, H. Corvid density and nest predation in relation to forest fragmentation: A landscape perspective. Ecology 1992, 73, 794-804. [CrossRef]

74. Bromberg, K.D.; Bertness, M.D. Reconstructing new England salt marsh losses using historical maps. Estuaries 2005, 28, 823-832. [CrossRef]

75. Angelstam, P.; Roberge, J.M.; Lõhmus, A.; Bergmanis, M.; Brazaitis, G.; Dönz-Breuss, M.; Edenius, L.; Kosinski, Z.; Kurlavicius, P.; Lārmanis, V.; et al. Habitat modelling as a tool for landscape-scale conservation: A review of parameters for focal forest birds. Ecol. Bull. 2004, 51, 427-453.

76. Angelstam, P.; Yamelynets, T.; Elbakidze, M.; Prots, B.; Manton, M. Gap analysis as a basis for strategic spatial planning of green infrastructure: A case study in the Ukrainian Carpathians. Écoscience 2017, 24, 41-58. [CrossRef]

77. Scott, J.M.; Davis, F.; Csuti, B.; Noss, R.; Butterfield, B.; Groves, C.; Anderson, H.; Caicco, S.; D’Erchia, F.; Edwards, T.C.; et al. Gap analysis: A geographic approach to protection of biological diversity. Wildl. Monogr. 1993, 123, 3-41.

78. Lõhmus, A.; Kohv, K.; Palo, A.; Viilma, K. Loss of old-growth, and the minimum need for strictly protected forests in Estonia. Ecol. Bull. 2004, 51, 401-411.

79. Manton, M.G.; Angelstam, P.; Mikusiński, G. Modelling habitat suitability for deciduous forest focal species-A sensitivity analysis using different satellite land cover data. Landsc. Ecol. 2005, 20, 827-839. [CrossRef]

80. Sala, O.E.; Paruelo, J.M. Ecosystem services in grasslands. In Nature's Services: Societal Dependence on Natural Ecosystems; Daily, G.C., Ed.; Island Press: Washington, DC, USA, 1997; pp. 237-251.

81. Beery, T.; Jönsson, K.I. Inspiring the outdoor experience: Does the path through a nature center lead out the door? J. Interpret. Res. 2015, 20, 67-85.

82. Tuvendal, M.; Elmberg, J. A handshake between markets and hierarchies: Geese as an example of successful collaborative management of ecosystem services. Sustainability 2015, 7, 15937-15954. [CrossRef]

83. Baker, S. Sustainable Development; Routledge: London, UK, 2006.

84. Johannessen, Å.; Hahn, T. Social learning towards a more adaptive paradigm? Reducing flood risk in Kristianstad municipality, Sweden. Glob. Environ. Chang. 2013, 23, 372-381. [CrossRef]

85. Tuvendal, M.; Elmqvist, T. Ecosystem services linking social and ecological systems: River brownification and the response of downstream stakeholders. Ecol. Soc. 2011, 16, 21. [CrossRef]

86. Ottvall, R.; Smith, H.G. Effects of an agri-environment scheme on wader populations of coastal meadows of southern Sweden. Agric. Ecosyst. Environ. 2006, 113, 264-271. [CrossRef]

87. Angelstam, P.; Barnes, G.; Elbakidze, M.; Marais, C.; Marsh, A.; Polonsky, S.; Richardson, D.M.; Rivers, N.; Shackleton, R.T.; Stafford, W. Collaborative learning to unlock investments for functional ecological infrastructure: Bridging barriers in social-ecological systems in South Africa. Ecosyst. Serv. 2017, 27, 291-304. [CrossRef]

88. Schultz, L.; Folke, C.; Olsson, P. Enhancing ecosystem management through social-ecological inventories: Lessons from Kristianstads Vattenrike, Sweden. Environ. Conserv. 2007, 34, 140-152. [CrossRef] 
89. Millennium Ecosystem Assessment. Ecosystems and Human Well-Being: Synthesis; Island Press: Washington, DC, USA, 2005.

90. Garrido, P.; Elbakidze, M.; Angelstam, P.; Plieninger, T.; Pulido, F.; Moreno, G. Stakeholders' benefits of wood pasture landscapes in Spain. Land Use Policy 2017, 60, 324-333. [CrossRef]

91. Huntsinger, L.; Oviedo, J.L. Ecosystem services are social-ecological services in a traditional pastoral system: The case of California's Mediterranean rangelands. Ecol. Soc. 2014, 19, 8. [CrossRef]

92. Benstead, P.; Jose, P.; Joyce, C.; Wade, P. European Wet Grassland: Guidelines for Management and Restoration; RSPB: Sandy, UK, 1999.

93. Angelstam, P.; Grodzynskyi, M.; Andersson, K.; Axelsson, R.; Elbakidze, M.; Khoroshev, A.; Kruhlov, I.; Naumov, V. Measurement, collaborative learning and research for sustainable use of ecosystem services: Landscape concepts and Europe as laboratory. AMBIO 2013, 42, 129-145. [CrossRef] [PubMed]

94. Gustavsson, E.; Lennartsson, T.; Emanuelsson, M. Land use more than 200 years ago explains current grassland plant diversity in a Swedish agricultural landscape. Biol. Conserv. 2007, 138, 47-59. [CrossRef]

(C) 2018 by the authors. Licensee MDPI, Basel, Switzerland. This article is an open access article distributed under the terms and conditions of the Creative Commons Attribution (CC BY) license (http:// creativecommons.org/licenses/by/4.0/). 